Article

\title{
Two Thousand Years of Land-Use and Vegetation Evolution in the Andean Highlands of Northern Chile Inferred from Pollen and Charcoal Analyses
}

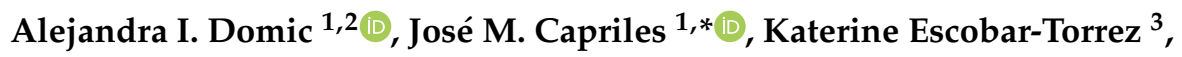 \\ Calogero M. Santoro 4 (D) and Antonio Maldonado ${ }^{2,5,6}$ \\ 1 Department of Anthropology, Pennsylvania State University, University Park, PA 16802, USA; \\ alejandradomic@gmail.com \\ 2 Centro de Estudios Avanzados en Zonas Áridas, Raul Bitran No. 1305, La Serena 1700000, Chile; \\ antonio.maldonado@ceaza.cl \\ 3 Herbario Nacional de Bolivia, Universidad Mayor de San Andrés, Cota Calle 27, La Paz 15000, Bolivia; \\ kescobar.torrez@gmail.com \\ 4 Instituto de Alta Investigación, Universidad de Tarapacá, Antofagasta 1520, Arica 100000, Chile; \\ calogero_santoro@yahoo.com \\ 5 Instituto de Investigación Multidisciplinario en Ciencia y Tecnología, Universidad de La Serena, \\ La Serena 1700000, Chile \\ 6 Departamento de Biología Marina, Universidad Católica del Norte, Larrondo 1281, Coquimbo 1781421, Chile \\ * Correspondence: juc555@psu.edu; Tel.: +1-814-865-7835
}

Academic Editors: Encarni Montoya, Bronwen S. Whitney and Valentí Rull Received: 1 October 2018; Accepted: 10 December 2018; Published: 19 December 2018

\begin{abstract}
The European conquest of the New World produced major socio-environmental reorganization in the Americas, but for many specific regions and ecosystems, we still do not understand how these changes occurred within a broader temporal framework. In this paper, we reconstruct the long-term environmental and vegetation changes experienced by high-altitude wetlands of the southcentral Andes over the last two millennia. Pollen and charcoal analyses of a 5.5-m-long core recovered from the semi-arid puna of northern Chile indicate that while climatic drivers influenced vegetation turnaround, human land use and management strategies significantly affected long-term changes. Our results indicate that the puna vegetation mostly dominated by grasslands and some peatland taxa stabilized during the late Holocene, xerophytic shrubs expanded during extremely dry events, and peatland vegetation persisted in relation to landscape-scale management strategies by Andean pastoralist societies. Environmental changes produced during the post-conquest period included the introduction of exotic taxa, such as clovers, associated with the translocation of exotic herding animals (sheep, cattle, and donkeys) and a deterioration in the management of highland wetlands.
\end{abstract}

Keywords: Holocene; human impact; environmental change; socio-ecological systems; camelid pastoralism; microcharcoal

\section{Introduction}

The European conquest of the New World produced major transformations in the socio-environmental systems that evolved in the continent for several millennia [1,2]. Some of the socio-ecological effects that this event produced include demographic collapse, reorganization of the socio-political systems, disruption of previous resource management practices, biodiversity loss, and the translocation of new species of animals and plants [3,4]. Although some regions experienced more direct and dramatic changes than others did, the entire hemisphere experienced significant 
socio-ecological reorganization. Paleo-ecological reconstructions have shown an intensification of land use following European settlements in some regions. For example, intense deforestation and land clearing allowed large-scale farming during post-colonial times in the Dominican Republic $[5,6]$, and large forests were burned and logged for pastures for livestock raising in northern and southern Patagonia $[7,8]$.

In the Andes, although we know much about the significant demographic and socio-political changes that the European conquest produced [9,10], only a few studies have addressed the resulting ecological effects. Part of the problem is that very few regional syntheses describe specific trajectories of socio-ecological change (but see [11-13]). For instance, in the Andean highlands, an immediate process occurring after the Spanish conquest was an exponential increase in mining activities that directly produced a significant increase in pollution and deforestation [14,15]. Nevertheless, post-colonial land use also involved the introduction of new domesticated animals including cattle, sheep, goats, pigs, and donkeys, but also the introduction of new cultigens such as wheat, barley, and fava beans, as well as a number of unintentional weeds [14-19]. Although some direct effects of these processes included the replacement of native domesticated camelid herds and cultigens such as maize and quinoa, other direct and indirect effects of this process remain poorly investigated. Moreover, to improve our understanding of the scale and nature of these changes, it is necessary to untangle the long-term trajectories of climatic and socio-ecological change. In this paper, we address the problem of how Andean vegetation responded to the interaction between land-use intensification and extreme climatic events before and after the European conquest. Using data from a pollen record and informed by the archaeological and paleo-ecological records of the area, we evaluated the various transformations that vegetation underwent in the south central Andean of northern Chile and neighboring areas of southern Peru and western Bolivia in the south central Andes.

Paleo-ecological studies suggest that the current distribution and composition of high-Andean ecosystems is the product of both humans and climate change. During the Last Glacial Maximum (LGM), glacier expansion restricted the presence of Andean woodlands above $4000 \mathrm{~m}$ above sea level (a.s.1.) causing their migration to protected sites and lower elevations [20-23]. Subsequently, as conditions became warmer and more humid during the glacial-interglacial transition, grasslands and woodlands expanded across the Altiplano [24,25]. During the mid-Holocene, however, aridity prevailed, producing expansion of sclerophyllous shrubs and drying of some lakes and wetlands [26-28]. Loss of woody vegetation was enhanced by anthropogenic disturbance as firewood extraction and landscape transformation intensified, particularly after agro-pastoralism became the main subsistence strategy throughout much of the Andes, starting around 3500 years ago [29-31].

Although human disturbance has played a major role on the present-day distribution and abundance of Andean vegetation, there are still large gaps in information regarding past anthropogenic impacts. Andean people traditionally used, and even actively managed, grasslands and peatlands as grazing areas, and woodlands and shrublands as sources of firewood, building material, and raw material for manufacturing tools [26,32]. Grasslands and woodlands were also important as hunting and gathering places, which occasionally involved using fire $[8,33]$. Although anthropogenic fire is considered the leading cause of vegetation loss and degradation in the past [30], evidence shows that wild fires were a recurrent event in the central highlands of the Andes, even before human arrival $[23,31,34]$. For example, in southern Peru and central Bolivia, pollen of the Andean tree Polylepis decreased significantly and in correspondence to increased abundance of charcoal related to lighting and drought events, suggesting that although burning inhibited the expansion of woodlands and even produced their local disappearance, it might not have been produced by human agency $[20,21,25,35,36]$.

Several paleo-ecological studies provide relevant information regarding past variation of Andean vegetation, but most of these studies are focused on the eastern slopes of the Andes, with a few exceptions covering the western semi-arid highlands [33,36,37]. In this study, we rely on a paleo-ecological approach to reconstruct past vegetation and fire history of the semi-arid Andes of northern Chile, a region characterized by extreme conditions (freezing night temperatures, high 
solar irradiance, and scarce precipitation), by emphasizing anthropogenic effects, such as land-use management practices, as much as the potential effects of climate change. More specifically, to improve our understanding of the long-term history of human impact, we reconstructed past vegetation dynamics by analyzing fossil pollen and charcoal recovered from a sediment core collected on an Andean high-elevation peatland (also known as bofedal) located near a Polylepis tarapacana forest. An assessment of the role of human societies and the resilience of Andean vegetation to prehistoric and historic disturbance (e.g., fire, grazing) may contribute to a better understanding of the cultural legacy that the modern landscapes incorporate, and, therefore, to more accurately design policies for conservation of native ecosystems and adaptation to ongoing climate change.

\section{Materials and Methods}

\subsection{Study Site}

The study site, Cosapilla peatland $\left(17^{\circ} 47^{\prime} 10.62^{\prime \prime} \mathrm{S}, 69^{\circ} 25^{\prime} 46.20^{\prime \prime} \mathrm{W}, 4380 \mathrm{~m}\right.$ a.s.l.), is located on the Andean Altiplano of northern Chile (Figure 1). Specifically, the core location was situated in the middle of a bofedal associated with a small herding settlement and in the vicinity of a Polylepis tarapacana forest patch. The region is situated in a volcanically active region, although most eruptions occur at very long temporal scales [38]. Three stratovolcanoes in the vicinity reach elevations higher than 6000 m: Parinacota (6342 m), Pomerape (6240 m), and Sajama (6452 m).

In the region, semi-arid and cold conditions prevail, with an average mean annual temperature of $4.2^{\circ} \mathrm{C}$ and an average total annual precipitation of $300-350 \mathrm{~mm}^{-1}$ [38]. Most of the precipitation (90\%) falls during the austral summer, between November and March. The austral winter (April-October) is characterized by little precipitation, night freeze temperatures, high solar irradiance, and low cloud cover. Drastic fluctuations in temperature are experienced during the day; temperature extremes from high to low can be as much as $30^{\circ} \mathrm{C}$. El Niño Southern Oscillation (ENSO) mainly drives the inter-annual climate variability. During ENSO events, dry conditions prevail in the region through the austral summer. In contrast, during the La Niña events, wet conditions are common and snow cover on glaciers persists into the summer in relation to increased cloudiness, lower temperatures, and increased precipitation.

The vegetation of the study area is typical of the dry puna. The landscape is characterized by the presence of Andean peatlands, tussock grasslands dominated by Festuca orthophylla, sclerophyllous shrubs of Baccharis thola and Parastrephia spp., and patches of Polylepis tarapacana woodlands [38,39]. Small shrubs such as Adesmia spinosissima, Fabiana densa, and Tetraglochin cristatum are also common in the region. The vegetation of Andean peatlands is typically dominated by hygrophilous forbs (Cypearceae and Juncaceae) and small grasses [40,41]. Oxychloe andina, Distichia muscoides, and Plantago tubulosa form compact cushions that constitute the habitat for several small forbs. Peatlands provide key environmental services, including carbon sequestration, regulation of water influx, soil protection, and habitat for native fauna [42]. Moreover, herders consider Andean peatlands one of the most important grazing areas because they provide forage rich in protein for livestock [43]. Occasionally, saltpans are closely located to peatlands, where saline-tolerant species (Sarcocornia pulvinata, Frankenia triandra, and Atriplex nitrophiloides) are commonly found. 


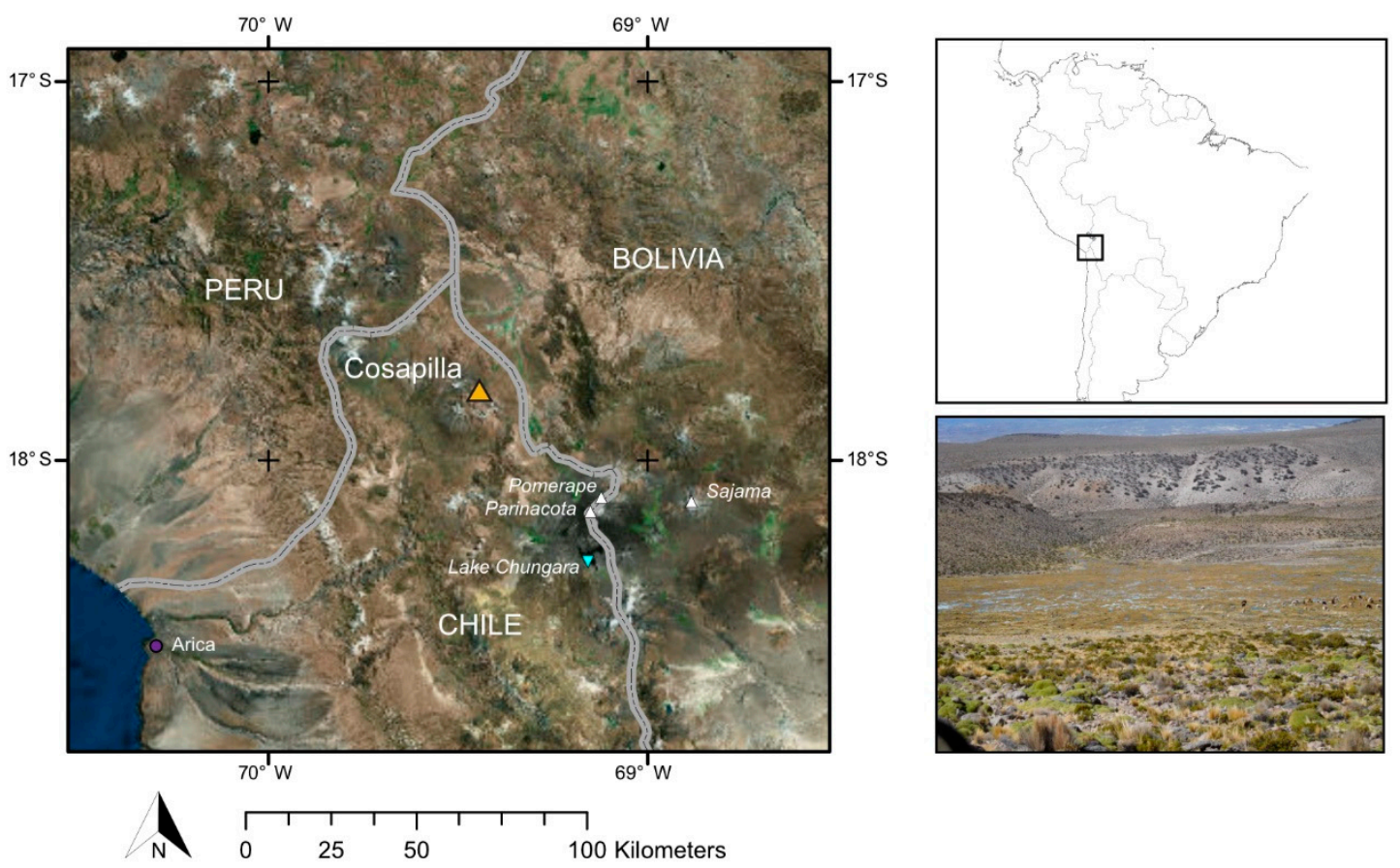

Figure 1. Map of north semi-arid Andes of Chile showing the location of the Cosapilla peatland.

\subsection{Sampling and Processing}

In 2016, one sediment core was retrieved from an Andean peatland in 50-cm sections with a Russian corer, to a maximum depth of $550 \mathrm{~cm}$. Core sections were packed and transported to the palynology lab at the Centro de Estudios Avanzados en Zonas Áridas (CEAZA) in La Serena, Chile. We characterized the lithology of the sediment cores based on field assessments of the stratigraphy, and later observations derived from $X$-ray radiographs. We determined the content of organic and inorganic (carbonates and clastic fraction) matter by collecting $1-\mathrm{cm}^{3}$ sediment subsamples every centimeter and conducting Loss-on-Ignition (LOI) [44,45].

We collected sediment sub-samples every $4-7 \mathrm{~cm}$ for pollen and microscopic charcoal analysis (69 samples in total). We added 2 Lycopodium tablets to calculate pollen concentration and pollen influx. We used standardized pollen techniques to process soil samples, including $\mathrm{HCl}, \mathrm{KOH}, \mathrm{HF}$, and acetolysis [46]. Optical microscopy $(400 \times)$ was used to identify pollen grains. In each sample, we identified a minimum of 300 pollen grains, excluding Cyperaceae and other local aquatic taxa. We identified pollen grains using palynological atlases [47-50], pollen keys, and the pollen reference collections at CEAZA and the Herbario Nacional de Bolivia.

Microcharcoal concentration was determined in the same samples as counted for pollen and spore analysis. We counted microscopic charcoal particles larger than $10 \mu \mathrm{m}$ size and Lycopodium spores on 200 fields of view selected randomly. Microcharcoal particles were categorized either as woody or herbaceous particles based on their morphology. We identified herbaceous charcoal as particles with presence of stomata within epidermal cells and a flat surface, and we considered that they come from grasses or other monocots [51]. We estimated charcoal concentration values by counting the number of Lycopodium spores.

We constructed a core chronology by using ${ }^{14} \mathrm{C}$ accelerator mass spectrometry (AMS) dates on seven bulk organic samples. All samples for radiocarbon dating were analyzed at the DirectAMS radiocarbon lab. We calibrated the radiocarbon dates by using the Southern Hemisphere calibration curve SHCAL13 [52]. We calibrated the samples and generated a Bayesian age-depth model with the Bacon package version 2.2 [53] in R (https:/ / www.r-project.org/). The model was built under the assumption that the top of the sequence corresponds to the year of core retrieval (2016 CE). 


\subsection{Statistical Analysis}

We used the pollen sum to calculate relative abundances of each taxon, which was expressed as percentages. We assigned pollen taxa to a vegetation type based on fieldwork and bibliographic references $[39,41,50,54]$. We created pollen diagrams using pollen percentages with Tilia and Tilia Graph. Pollen zones were determined using the stratigraphically-constrained incremental sum of square clustering (CONISS 1.5.12). The method works by combining the two most similar and stratigraphically adjacent samples [55]. We performed a multivariate analysis to detect differences in the composition of the pollen assemblage between different pollen intervals. A detrended correspondence analysis (DCA) was conducted using all pollen taxa present at abundances higher than $2 \%$ and recorded in more than five samples. We performed a DCA to detect major compositional changes and species turnover of dominant taxa through time. The Vegan package of $\mathrm{R}$ statistical software (version 3.4.2, R Foundation for Statistical Computing, Vienna, Austria) was used to perform the analysis.

\section{Results}

\subsection{Chronology and Lithological Description}

The AMS radiocarbon dates from the sediments provided a consistent chronology with an absence of anomalous dates (Table 1). The earliest date, near the bottom of the core, dates to approximately 7702 calendar year BP. A second date, situated a meter above, dates to 1404 calendar year BP, suggesting a greater compaction in the lowermost meter of deposition, thus a greater temporal resolution in the upper $480 \mathrm{~cm}$. The age-deposition model shows a phase of initial slow sedimentation between $\sim 7700$ and $\sim 1400$ calendar year BP $(0.04 \pm 0.013 \mathrm{~mm} / \mathrm{y})$, followed by a period of decreased deposition $(0.5-1 \mathrm{~cm} / \mathrm{y})$ that continued up to $2.3 \mathrm{~m}$ (ca. 200 calendar year BP), and a third period of increased deposition rate $(0.16 \pm 0.08 \mathrm{~mm} / \mathrm{y})$ (Figure 2$)$.

The sediment of the core is characterized by the abundance of peat soil, intermixed with layers of higher silt and sand content (Figure 3). The base of the core is composed mainly of fine and compact layers of sand and silt wit. One sandy layer was observed at $350 \mathrm{~cm}$ in depth. The loss-on-ignition analysis showed high abundance of inorganic material and carbonates (75-97\%) between 550 and $400 \mathrm{~cm}$ depth and high content of organic material (75-98\%) between $400 \mathrm{~cm}$ and the top of the core. The abundance of carbonate was constantly scarce throughout the sediment core $(<5 \%)$.

Table 1. Radiocarbon ages of the Cosapilla 0016-B core from a peatland in the semi-arid Andes of northern Chile. The modeled ages (mean and standard deviation) are the result of a probabilistic age-depth model.

\begin{tabular}{ccccc}
\hline Lab Code & Core Depth $\mathbf{( c m )}$ & ${ }^{\mathbf{1 4}}$ C Years BP & Error & $\begin{array}{c}\text { Calibrated Age } \\
\text { (Calendar Year BP) }\end{array}$ \\
\hline D-AMS-028556 & 48.5 & modern & & - \\
D-AMS-028557 & 116.5 & 87 & 28 & $66 \pm 28$ \\
D-AMS-028558 & 228.5 & 129 & 26 & $91 \pm 26$ \\
D-AMS-028559 & 297.5 & 665 & 32 & $605 \pm 32$ \\
D-AMS-028560 & 356.5 & 1316 & 23 & $1224 \pm 23$ \\
D-AMS-028561 & 428.5 & 1571 & 22 & $1404 \pm 22$ \\
D-AMS-028562 & 550 & 6912 & 25 & $7702 \pm 38$ \\
\hline
\end{tabular}


A
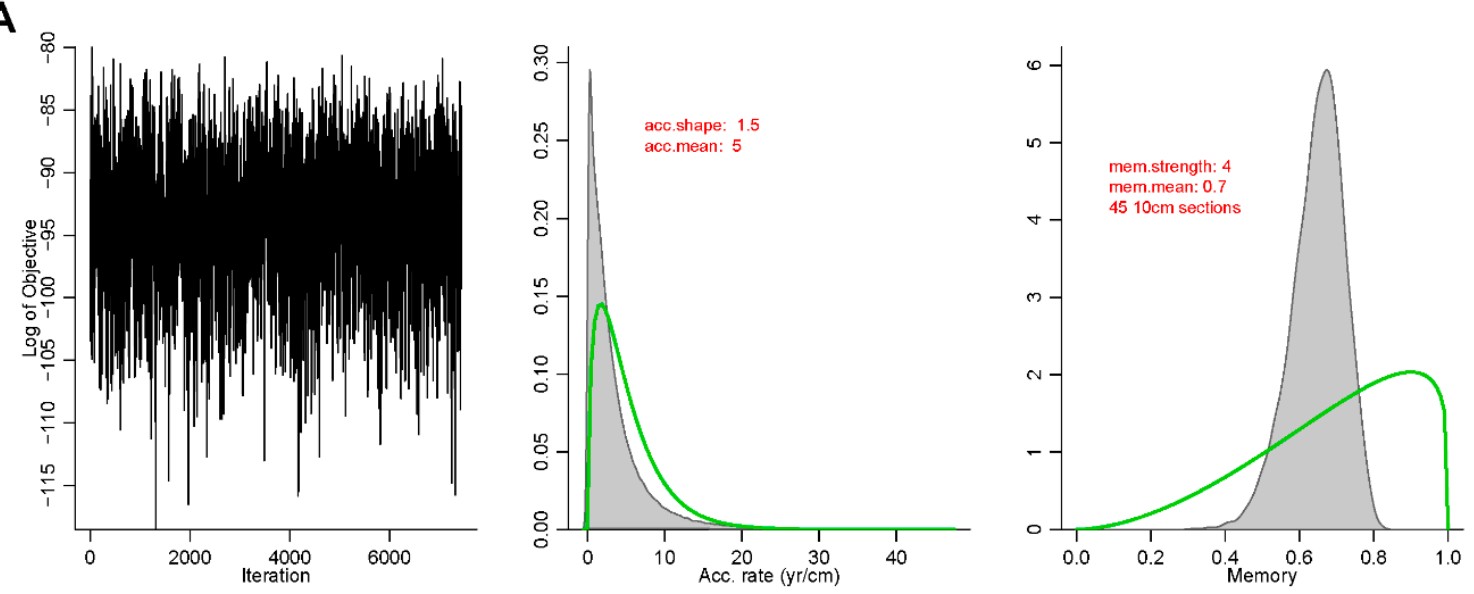

B

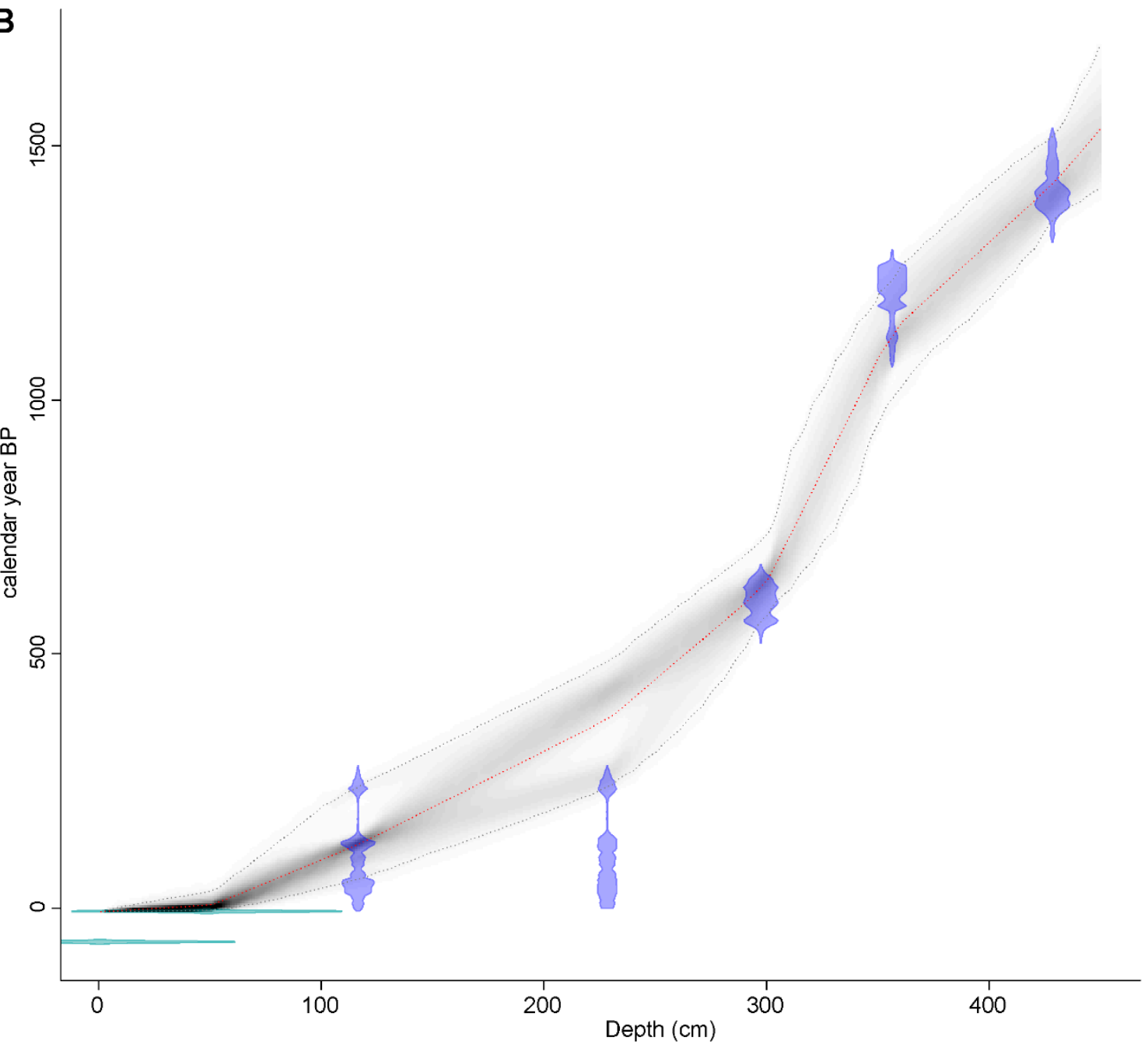

Figure 2. Bacon modeling routine output graph of age-depth model of Cosapilla 0016-B core based on radiocarbon dates. (A) Markov chain Monte Carlo iteration, prior (green curves)/posterior (grey histograms) distributions of accumulation rate and memory R of Cosapilla 0016-B core, (B) calibrated radiocarbon dates (blue), and age-depth model (dotted grey lines indicate more likely calendar ages; grey dashed lines show 95\% confidence intervals, and blue curve shows single "best" model based on the weighted mean age for each depth). 


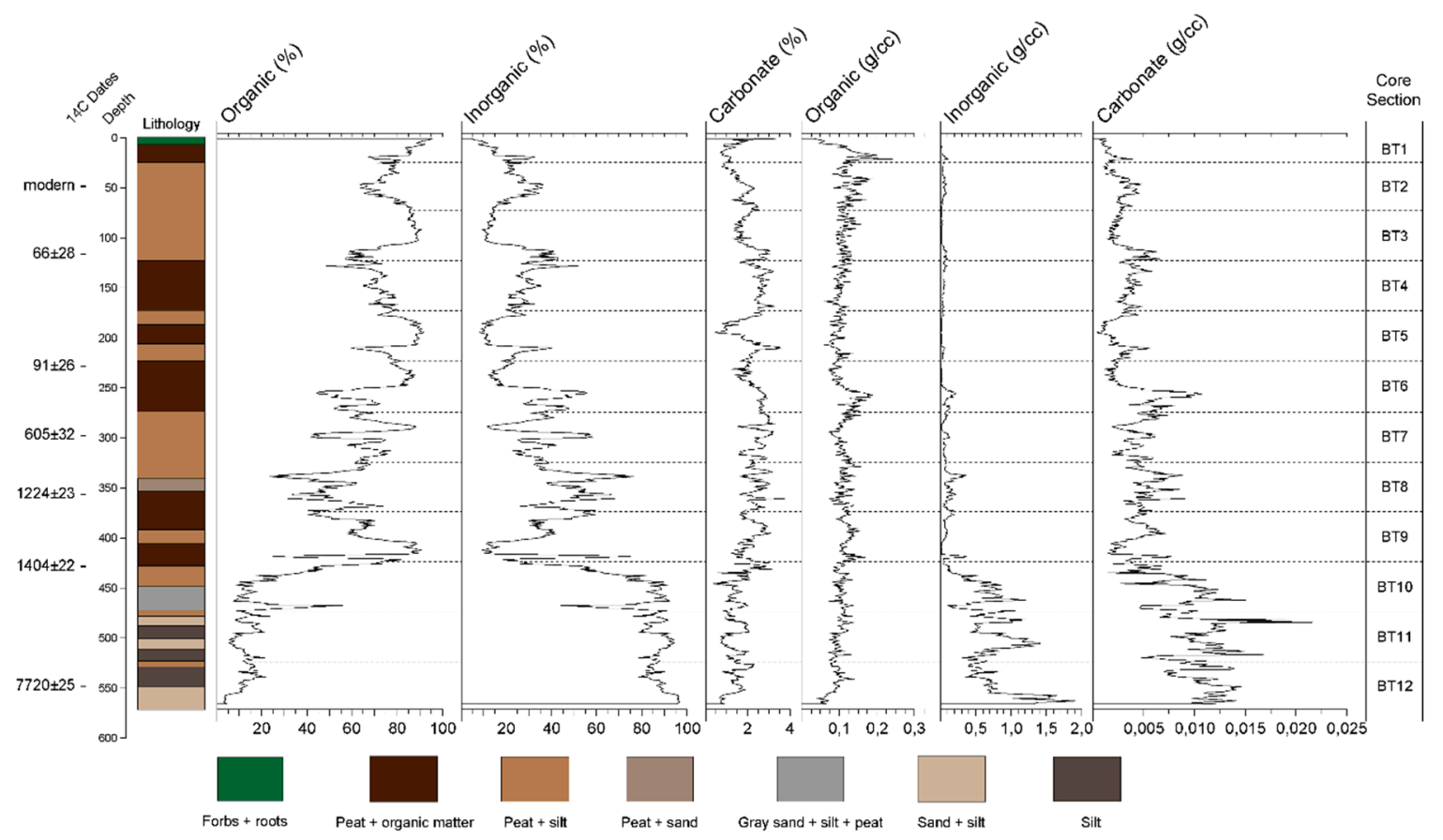

Figure 3. Percentage and concentration of carbonates, inorganics, and organics of Cosapilla 0016-B core from a peatland in the semi-arid Andes of northern Chile, including calibrated radiocarbon dates.

\subsection{Microfossil Analysis}

Pollen concentration was variable throughout the core, as well as pollen richness, as we identified only 24 distinct pollen types. Pollen preservation was highest at the base of the core, between 550 and $428 \mathrm{~cm}$ in depth, with a mean concentration of $57,574.37$ grains $/ \mathrm{cc}^{3}$. In contrast, the upper core section showed a mean pollen concentration of 22,248.59 grains $/ \mathrm{cc}^{3}$, with a peak of at $325 \mathrm{~cm}$ of 146,525 grains $/ \mathrm{cm}^{3}$. A cluster analysis identified five major zones within the sequence; $\mathrm{Z1}$ and Z2 had a predominance of grassland taxa, whereas $Z 3-Z 5$ comprised a higher proportion of peatland vegetation (Figures 4 and 5). Overall, Poaceae was the most dominant taxa, making up nearly $80 \%$ of the pollen assemblage and reflecting the dominance of grasslands in the area over time. The second most abundant pollen types were Asteraceae (Asteroideae and Gnaphaliae) and Baccharis-type, with abundances ranging between $5 \%$ and $60 \%$. Polylepis is the only native tree taxon found in the region and its pollen was present in low frequencies. The peatland vegetation was characterized by the presence of Apium, Cyperaceae, Eleochaeris, Gentiana, Myriophyllum, and Plantago. Other pollen types included Amaranthaceae, Caryophyllaceae, Ephedra, and Fabaceae. Disturbance taxa included Trifolium. Extra-regional taxa included Alnus, Podocarpus, Psichotria, Ulmaceae, Lauraceae, Melastomataceae, Moraceae, Piperaceae, Sisymbrium, and Smilax. Proxy data suggested five distinct past vegetation communities (Figure 4).

The DCA analysis of Cosapilla records resulted in four ordination axes (Figure 6). The first two axes had eigenvalues of 0.36 and 0.19 , respectively. Pollen assemblages were divided based on pollen zones identified by the Cluster Analysis. Samples from pollen zones Z1 and Z5 showed a distinct separation in space, as they rarely overlapped with the other pollen zones, indicating that the species composition is unique. In contrast, pollen zones Z2, Z3, and Z4 showed a larger overlap among each, other indicating that they share the same taxa. 

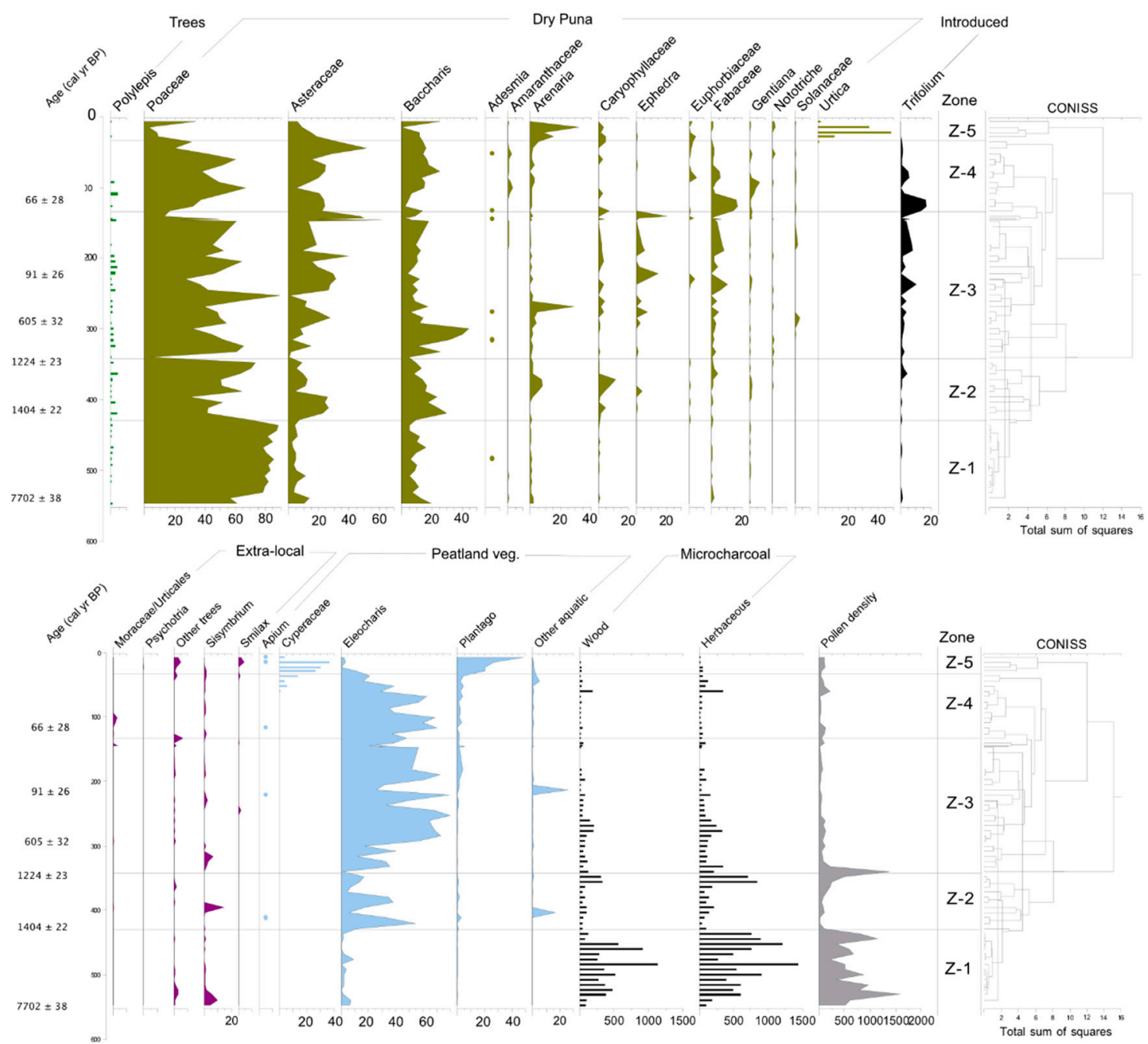

Figure 4. Pollen, palynomporphs, and microcharcoal diagram of Cosapilla 0016-B core from a peatland, northern Chile. Peatland vegetation and ferns were excluded from pollen count. 


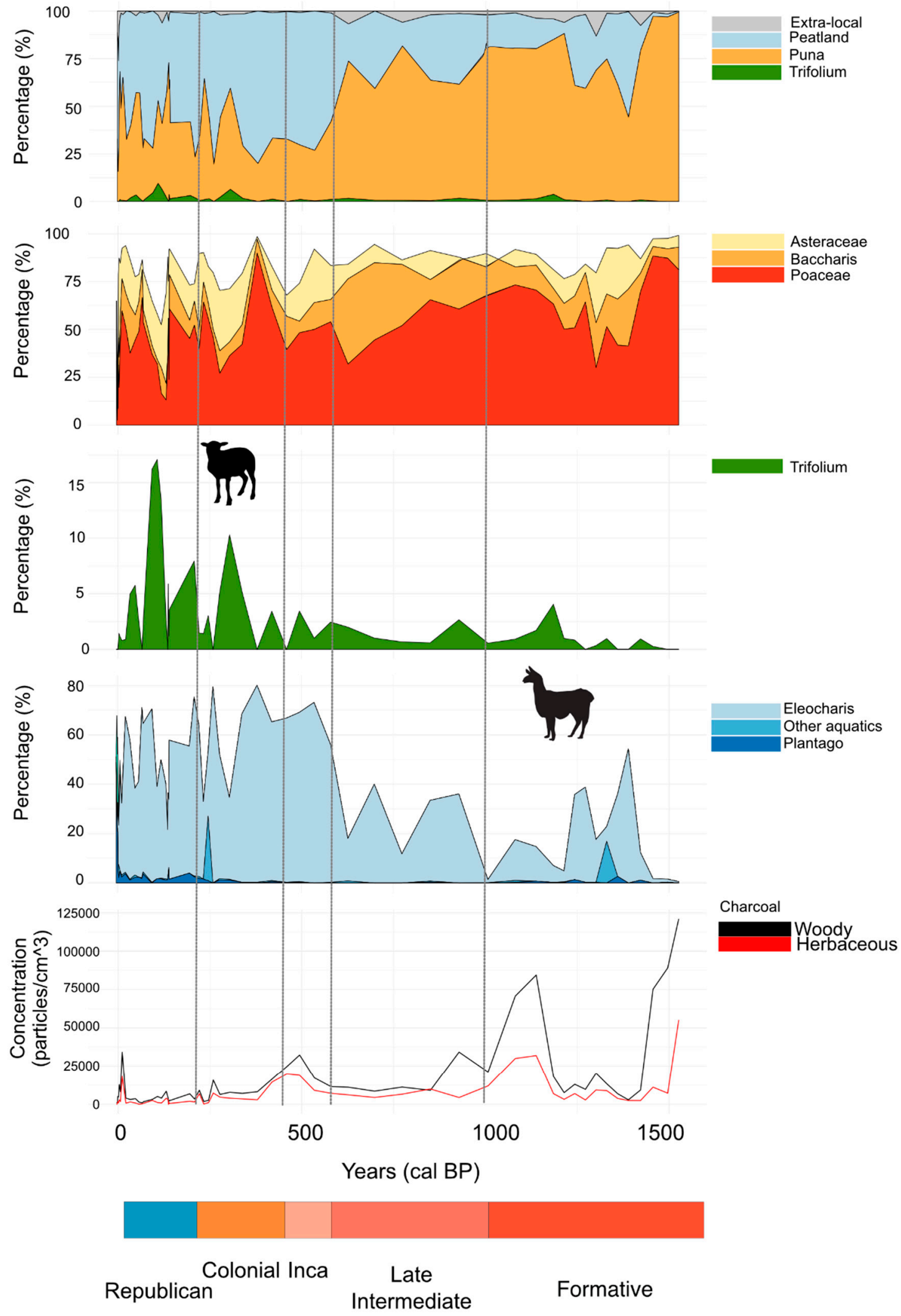

Figure 5. Abbreviated pollen percentage diagram for the last 200 year BP from the Cosapilla 0016-B core from a peatland in the semi-arid Andes of northern Chile. 


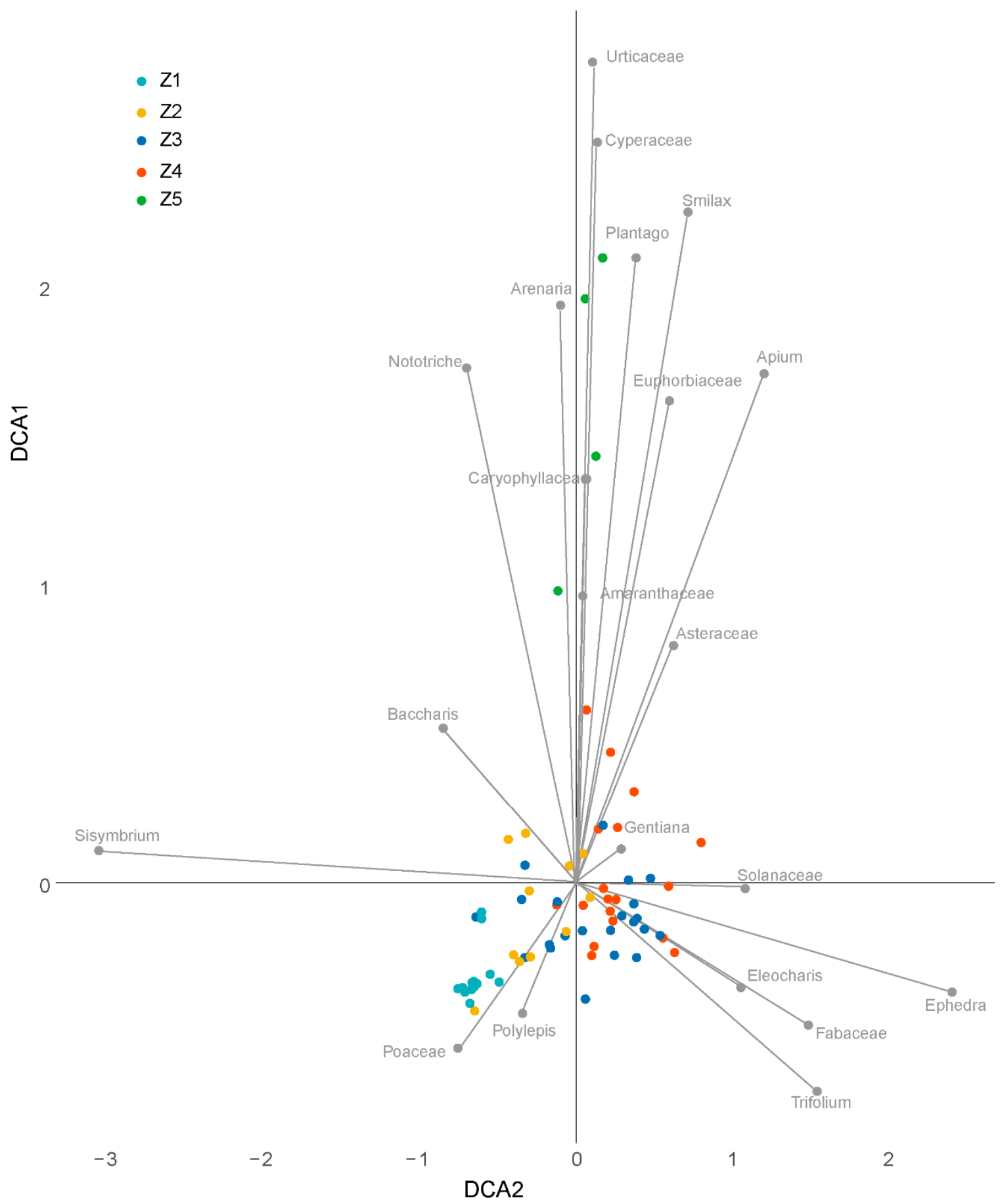

Figure 6. Detrended correspondence analysis (DCA) of pollen zones of Cosapilla 0016-B core from a peatland in the semi-arid Andes of northern Chile.

\subsubsection{Pollen Zone Z1 (550-435 cm; 7737-1460 calendar year BP)}

Poaceae pollen is by far the most abundant taxon, reaching up to $80 \%$. Asteraceae and Baccharis-type are considerably less common, with abundances lower than $20 \%$. Other pollen taxa including peatland vegetation are rare or infrequent. Microcharcoal particles, particularly herbaceous, are extremely abundant through the entire pollen zone (woody $=38.261$ particles $/ \mathrm{cm}^{3}$, herbaceous $=64,014.86$ particles $/ \mathrm{cm}^{3}$ ). This zone suggests moderate humidity and presence of vegetation characteristic of the puna. 


\subsubsection{Pollen Zone Z2 (350-435 cm; $1460-1250$ calendar year BP)}

Poaceae is the most abundant pollen taxon as it reaches up to $60 \%$. In contrast, pollen taxa characteristic of shrubland vegetation (Asteraceae and Baccharis-type) are less common ( 20\%). Other high-Andean pollen elements, in particular Arenaria $(<10 \%)$, are also present at very low abundances. Eleochaeris pollen fluctuates throughout the zone $(\sim 10-80 \%)$, but its presence signals the establishment of the Andean peatland. Microcharcoal particles fluctuate towards a decrease at the base of the pollen zone $\left(\right.$ woody $=7941.1$ particles $/ \mathrm{cm}^{3}$, herbaceous $=18,596.2$ particles $/ \mathrm{cm}^{3}$ ). This zone represents the transition from relatively humid grasslands to increasingly dry puna.

\subsubsection{Pollen Zone Z3 (150-350 cm; 1250-125 calendar year BP)}

Poaceae (5-80\%) and Asteraceae (up to 40\%) exhibit the highest values. Pollen of Baccharis-type is abundant (up to $40 \%$ ) at the base but decreases in abundance $(<20 \%)$ towards the end of the pollen zone. Other local pollen taxa include Arenaria, Caryophyllaceae, Euphorbiaceae, Ephedra, and Solanaceae. Pollen of Trifolium increases in abundance towards the end of the pollen zone (up to $~ 15 \%$ ). Eleocharis is the dominant taxon of the peatland, reaching values up to $65 \%$. Microcharcoal particles are comparatively more abundant (woody $=8095.68$ particles $/ \mathrm{cm}^{3}$, herbaceous $=15,377.54$ particles $/ \mathrm{cm}^{3}$ ), particularly near 500 calendar year BP. This zone marks a transition from dominant grasslands to a peatland, likely in relation to increased regional humidity.

\subsubsection{Pollen Zone Z4 (30-150 cm; $125-0$ calendar year BP)}

Poaceae pollen is the most abundant taxon, reaching up to $55 \%$. This zone is also characterized by the abundance of Asteraceae ( $\sim 50 \%$ ), Baccharis-type ( 5-40\%), and Eleocharis $(20-70 \%)$ pollen. Polylepis pollen is in general very low $(<5 \%)$ and is absent in the record from 30 to $75 \mathrm{~cm}$ in depth. Asteraceae pollen is the most abundant at the base of the zone but it decreases over time, while Poaceae becomes more abundant.

The remaining local flora include herbaceous and shrub taxa characteristic of the puna belt (4000 m a.s.l) [39]. Amaranthaceae (including Gomphrena), Caryophyllaceae, Euphorbiaceae, Ephedra, and Nototriche are common elements of the puna vegetation. Trifolium pollen is very abundant in the zone, reaching $15 \%$ in abundance. The peatland vegetation is characterized by the dominance of Eleocharis (up to $80 \%$ ). Microcharcoal particles, both woody and herbaceous, are found in low abundances (woody $=2438.06$ particles $/ \mathrm{cm}^{3}$, herbaceous $=6147.76$ particles $/ \mathrm{cm}^{3}$ ). The richness of taxa found in this zone seems to be a consequence of a healthy peatland environment as well as adequate taphonomic conditions for the preservation of pollen.

\subsubsection{Pollen Zone Z5 (0-30 cm; 0-4 calendar year BP)}

This pollen zone is characterized by the abundance of Baccharis-type (up to 25\%), Arenaria (from 16 to 33\%), Plantago (from 23 to 50\%), and Urticaceae (from 3 to $48 \%$ ). Both Asteraceae and Poaceae exhibit varying percentages but Poaceae is more abundant at the base of the pollen zone. Abundance of microcharcoal particles was the lowest of the paleorecord (woody $=2212.5$ particles $/ \mathrm{cm}^{3}$, herbaceous $=5724.8$ particles $/ \mathrm{cm}^{3}$ ). This zone reflects the progressive desiccation that the modern peatland in the sample location is currently experiencing.

\section{Discussion}

The pollen record indicates that grasslands primarily dominated the semi-arid Andean landscape between 7700 and 1400 calendar year BP. This period was followed by a major turnover in the plant community characterized by the emergence of a mixed grassland-shrub community and the formation of a high-altitude peatland. A second major change in the landscape took place around 800 calendar year BP, marked by the retraction of grasslands, the expansion of the peatland, and the appearance of the exotic clover (Trifolium). Evidence of burning is documented throughout the record with two 
major peaks in fire activity, the largest between 7700 and 1400 calendar year BP and a second around 1200 calendar year BP.

The pollen assemblage shows that the high-Andean steppe was a dominant component of the landscape during the middle Holocene, when arid climatic conditions prevailed in the Andean Altiplano [28,54,56-61]. During this period, precipitation was much lower and variable than today [62-64]. Similar conditions have been documented in Quebrada Puripica [64], Laguna Miscanti [65,66], and Laguna del Negro Francisco [67] towards the south of the study area.

The formation of the Andean wetland occurred approximately around 1400 calendar year BP and reached its maximum extension between 600 calendar year BP and modern times, as indicated by the abundance of Eleocharis pollen and organic matter. The establishment of a permanently inundated wetland coincides with an increase in moisture levels during the late Holocene, reported extensively in South America, including the central Altiplano [57], northern and central Chile [67-71], and eastern and northwestern Argentina [72,73].

In Cosapilla, the abundance of xerophytic shrubs fluctuates in time but experiences an increase during 1400-1200 calendar year BP, 800-600 calendar year BP, and 400 calendar year BP-present times. The increase of Asteraceae and Baccharis during these periods coincides with events of extreme aridity, in particular the Little Ice Age recorded in the Sajama ice core [74-76]. An expansion of shrubs is associated with drier conditions, linked with a decrease in moisture conditions and precipitation over the Altiplano [77]. However, unlike other semi-arid sites in the puna [37,78], drought-resistant shrubs have remained as a common component of the vegetation in Cosapilla.

Although tree taxa were rare, Polylepis, the only tree growing in the region, is present in the paleo-record, albeit in very low frequencies. Moreover, despite the fact that a P. tarapacana woodland is closely located to the peatland, pollen abundance was lower than 5\%. Previous studies have shown that Polylepis pollen tends to travel short distances and that it tends to concentrate within the forest [48]. Several palynological studies highlight the decline in abundance of Polylepis in the late Holocene throughout the Andes, a trend that suggests intense deforestation due to increased burning and firewood extraction $[79,80]$. The evidence recovered in this study, indicates that Polylepis pollen likely represents a local signal, and that small woodlands were present on mountain slopes near the peatland during the late Holocene, even at the time of increase in the demand for fuel and growing human population. Analogous pollen records from the region show that Polylepis woodlands were a common element of the vegetation, but they were unlikely to have covered large areas $[36,37,78]$.

The paleorecord shows evidence of regional fire during the early and middle Holocene. Fire activity in pollen zones Z1 and Z2 coincide with volcanic eruptions inferred from several tephra layers and high concentrations of Fe in a sediment core from Lake Chungara [61,81]. This overlap suggests that volcanic eruptions were one possible ignition source of regional fires and that charcoal particles were locally transported to the site during events of volcanic eruption. The impact of volcanic eruptions on vegetation is closely associated with the type and quantity of tephra deposited on the surface [82]. The pollen assemblage shows minor fluctuations in time, indicating that the amount of volcanic ash deposited in the site was not significant enough to induce mayor changes in population dynamics and the reconfiguration of the vegetation community. The large abundance of Poaceae and Asteraceae pollen before and after 7000 calendar year BP implies little disturbance on the local vegetation community. However, it is important to note that the slow sedimentation rate until 1400 calendar year BP could have produced the accumulation of charcoal and the temporal variability in sedimentation, challenging our ability to accurately discern the temporal fidelity of total charcoal accumulation as a fire proxy. Thus, these results should be taken with consideration.

Alternatively, the high frequency of wood and herbaceous charcoal could be the result of burning of vegetation by human groups and enhanced by dry conditions. Human groups were present in the highland Andes since approximately 12,000 calendar year BP and played a role in vegetation dynamics in the region [81,83-85]. High-altitude human foragers were particularly mobile between the early and middle Holocene, which could have produced a patchy distribution of temporary residential 
and logistical camps [86]. The high density of microcharcoal particles in pollen zones Z1 and Z2 may also suggest that hunter gatherers were using fire for hunting wild camelids (Vicugna vicugna and Lama guanicoe), taruka deer (Hippocamelus antisensis), and lesser rheas (Rhea pennata). Although archeological evidence from Hakenasa and other rock shelters in the region suggests decreased occupation intensity during the middle Holocene as a possible response to increased regional aridity [85-87], abundant wood and herbaceous charcoal particles during this period might suggest a more conspicuous presence by human foragers. In this context, it should be noted that Cosapilla is a large wetland in comparison with the Hakenasa surrounding. This suggests that Cosapilla could have acted as an eco-refuge, as defined by Núñez et al. 2013 ([86], see also [71]), for the highlands of Salar de Atacama; meaning that people looked for localized rich environments that contrasted with depleted regional conditions [86]. Field archeological surveys in the study area are needed to test for this alternative explanation.

Fire continues as a common element in the landscape during the Formative period later in the Holocene, as hunter-gatherers were progressively replaced by camelid pastoralists [27,87]. Pastoralism is an economic activity widely distributed in the Andean puna and herders traditionally use grasslands and wetlands as grazing areas for domestic camelids (llamas and alpacas). Herders could have used fire to actively manage pastures for their livestock (Figure 4). The abundance of Poaceae pollen and herbaceous charcoal indicates that grasslands were intentionally burned to promote re-sprouting and to encourage the development of more palatable foraging plants such as Festuca and Deyeuxia for domestic camelids [83].

A major shift in pollen assemblage is observed around the middle Formative ( 1300 calendar year BP) and Late Intermediate period ( $\sim 800$ calendar year BP) (Figure 5). The pollen record shows a decrease in grasslands, with an expansion of sclerophyllous vegetation (Asteraceae and Baccharis). Because this shift is correlated to decreased burning, fire suppression could have played an important role on vegetation dynamics. Modern experimental studies in the Argentinian Andes have shown that fire suppression favors establishment of shrubs but limits regeneration of tussock grasses [88]. Carrilla et al. [89] also showed that despite fire reduced aboveground biomass of burned vegetation, it promoted re-sprouting of tussock grasses. Other studies have shown, nevertheless, that burning has a detrimental effect on the overall plant community and biomass productivity [90], suggesting that long-term and comparative studies are needed to understand the magnitude of the effects of burning on Andean ecosystems.

The most significant landscape-modification strategy employed by pastoralists over the last 2000 years was probably increasing the surface of peatlands and wetland as grazing areas. In fact, indigenous groups may have also played an important role on the maintenance and expansion of the Andean wetland in Cosapilla. Ethnographic evidence shows that Andean herders usually managed bofedales by constructing and maintaining irrigated systems that increase water quantity and water availability during the dry and cold season [91,92]. The establishment of the peatland took place during the late Holocene Formative period, when the economy was mostly based on camelid pastoralism and peatlands were important grazing areas, suggesting that herders actively engaged in the development of the wetland in the study site.

The posterior expansion of the peatland coincides with the arrival of the Inca to the region, when climatic conditions were relatively stable. An increase in the area covered by the peatland suggests that it could have been used as a grazing area for a large density of camelids (particularly alpacas). This interpretation is supported by an increase in organic matter concentration, possible related to higher levels of animal excreta. The most common peatland taxa, Eleocharis, is commonly consumed by domestic camelids and livestock $[93,94]$ and is able to tolerate high grazing pressures [95]. Furthermore, results suggest a shift in herding strategies, from managing pastures with abundance of highly lignified and short tussock grasses, to managing wetlands characterized by the abundance of moist and succulent herbs available throughout the entire year $[96,97]$. 
The evidence of European conquest on the Andes is also present in the pollen record. After the Spanish conquest, peatland pollen continues to be abundant and probably represents the continual effort of the local population to maintain the wetland for grazing of domestic camelids and introduced livestock. Pollen of the exotic clover (Trifolium) becomes abundant between 600 and 100 year BP, possibly in relation to the translocation of sheep and cattle herds [7,98]. Currently, Andean pastoralists keep mixed herds of native and exotic animals as a way to diversify their economy [99,100]. While the native camelids might not be as profitable as sheep and cattle, they fair better during droughts and frosts and require less supervision. The environmental impact of cattle and sheep is also considerably higher than llamas and alpacas because the former uproot and trample vegetation and consume more pasture than camelids [91]. It is quite possible that the intensification of livestock raising produced overgrazing and soil erosion, facilitating the establishment of exotic weeds, including Trifolium [95,101].

In recent times, the Cosapilla peatland has experienced a mild retraction with an associated expansion of grasslands and shrubs. The appearance of Plantago and an abrupt increase of Trifolium could suggest a decrease of traditional management and a degradation of the peatland, favoring the establishment of species resistant to trampling and increased herd browsing pressure. Currently, some highland Andean wetlands located near the study area show clear signs of degradation due to climate change and loss of human traditional management practices, which are inducing the reorganization of plant communities. The overall trend suggests that during the last 2000 years, changes in vegetation dynamics were affected by climatic events as much as anthropogenic disturbance [71,102].

Charcoal concentration decreased over time but it remained relatively frequent throughout the record during colonial and republican times. The burning of vegetation by pastoralists can also be related to scaring away predators (foxes and pumas) from camelid herds. This indicates that burning persisted as a common practice, probably associated with camelid herding in the region. Thus, it is likely that burning and grazing simultaneously shaped vegetation structure and plant cover in the semi-arid highlands over millennial scales [89]. Unlike Cosapilla, other paleorecords have shown a marked increase in fire intensity associated with land-use intensification after the European conquest [5-7]. For example, in Huila (Ecuador) and Chachapoal Valley (Chile), an intensification of burning took place during the Spanish settlement, probably in relation to land-clearing and land-use intensification $[103,104]$.

The paleoecology of Cosapilla does not evidence land use intensification or large-scale landscape transformation during colonial times. This pattern indicates that the predominant form of land use remained as extensive grazing, in which livestock (both camelids and introduced animals) were fed on forage from natural grasslands and wetlands. Alternatively, it could be attributed to land abandonment due to the demographic collapse and forced relocation of indigenous populations during the colony [71,105-108]. The Altiplano of Tarapacá suffered a second population decline associated with migration waves from the highlands to the coast from 1820 to 1960 [109]. The massive migration was stimulated by economic growth and demand of human labor, but also by a persistent decrease in precipitation in the Andean highlands $[77,108]$.

\section{Conclusions}

The paleo-ecological record from the Cosapilla peatland in the semi-arid Andes of northern Chile suggests that the environmental impact of anthropogenic activities has been significant over the last several millennia. Throughout time, humans have increasingly managed and modified this landscape, particularly with the emergence of an economic organization dependent on Andean camelid pastoralism. Extensive pastoralism of domesticated camelid herds seems to have involved fire to provide growth of palatable grass species, as much as the construction and management and increase of available peatlands. Camelid pastoralism also expanded the coverture of peatlands and changed the composition of plant communities towards hydrophytic vegetation and tussock grasses. Evidence of the arrival of Europeans to the region is reflected by the appearance of the exotic clover (Trifolium), probably connected to the translocation of exotic herding animals. The interaction between 
humans and increasing aridity favored the establishment of drought-tolerant vegetation and the reconfiguration of ecological communities in the Andean highlands. Finally, the ongoing changes in human management practices and climatic variability caused by anthropogenic global warming are currently favoring the establishment of drought-tolerant vegetation, a deterioration of wetland systems, and a new reorganization of the ecological communities in the Andes.

Author Contributions: Conceptualization, A.I.D., A.M.; methodology, A.M.; formal analysis, A.I.D., J.M.C.; investigation, A.I.D., K.E.-T., J.M.C., A.M.; resources, C.M.S., A.M.; data curation, A.I.D.; writing-original draft preparation, A.I.D., J.M.C.; writing—review and editing, A.I.D., J.M.C., K.E.-T., C.M.S., A.M.; visualization, A.I.D., J.M.C., A.M.; supervision, C.M.S., A.M.; project administration, A.I.D., C.M.S., A.M.; funding acquisition, A.I.D., J.M.C., C.M.S., A.M.

Funding: Funding for this project was facilitated by FONDECYT Postdoctoral Project $\mathrm{N}^{\circ} 3160443$, FONDECYT $\mathrm{N}^{\circ} 1181829$, and CONICYT PCI PII20150081.

Acknowledgments: We thank Maria Eugenia de Porras, Marigen Heise, Cesar Mayta, Rosa Isela Meneses, Douglas J. Kennett, Sarah Ivory, Duncan Christie, Richard Villegas, Teresa Ortuño, Ignacio Jara, Hospital Público San Juan de Dios in La Serena, and the editors and reviewers of Quaternary for their contributions during different stages of the project.

Conflicts of Interest: The authors declare no conflict of interest. The funders had no role in the design of the study; in the collection, analyses, or interpretation of data; in the writing of the manuscript, or in the decision to publish the results.

\section{References}

1. Crosby, A.W. The Columbian Exchange: Biological and Cultural Consequences of 1492; Greenwood Publishing Group: Santa Barbara, CA, USA, 2003; ISBN 978-0-275-98073-3.

2. Denevan, W.M. The pristine myth: The landscape of the Americas in 1492. Ann. Assoc. Am. Geogr. 1992, 82, 369-385. [CrossRef]

3. Mann, M. The Dark Side of Democracy: Explaining Ethnic Cleansing, 1st ed.; Cambridge University Press: Cambridge, UK, 2004; ISBN 978-0-521-53854-1.

4. Wheeler, J.C.; Russel, A.J.; Redden, H. Llamas and alpacas: Pre-conquest breeds and post-conquest hybrids. J. Archaeol. Sci. 1995, 22, 833-840. [CrossRef]

5. Castilla-Beltrán, A.; Hooghiemstra, H.; Hoogland, M.L.P.; Pagán-Jiménez, J.; van Geel, B.; Field, M.H.; Prins, M.; Donders, T.; Herrera Malatesta, E.; Ulloa Hung, J.; et al. Columbus' footprint in Hispaniola: A paleoenvironmental record of indigenous and colonial impacts on the landscape of the central Cibao Valley, northern Dominican Republic. Anthropocene 2018, 22, 66-80. [CrossRef]

6. Hooghiemstra, H.; Olijhoek, T.; Hoogland, M.; Prins, M.; van Geel, B.; Donders, T.; Gosling, W.; Hofman, C. Columbus' environmental impact in the New World: Land use change in the Yaque River valley, Dominican Republic. Holocene 2018, 28, 1818-1835. [CrossRef] [PubMed]

7. Huber, U.M.; Markgraf, V. European impact on fire regimes and vegetation dynamics at the steppe-forest ecotone of southern Patagonia. Holocene 2003, 13, 567-579. [CrossRef]

8. Veblen, T.T.; Kitzberger, T.; Villalba, R.; Donnegan, J. Fire history in northern Patagonia: The roles of humans and climatic variation. Ecol. Monogr. 1999, 69, 47-67. [CrossRef]

9. Rowe, J.H. Culture at the Time of the Spanish Conquest. In Handbook of South American Indians; Smithsonian Institution Press: Washington, DC, USA, 1946; pp. 183-330.

10. Cook, N.D. Demographic Collapse: Indian Peru, 1520-1620, 1st ed.; Cambridge University Press: Cambridge, UK, 2004; Volume 41.

11. Santoro, C.M.; Capriles, J.M.; Gayo, E.M.; de Porras, M.E.; Maldonado, A.; Standen, V.G.; Latorre, C.; Castro, V.; Angelo, D.; McRostie, V.; et al. Continuities and discontinuities in the socio-environmental systems of the Atacama Desert during the last 13,000 years. J. Anthropol. Archaeol. 2017, 46, 28-39. [CrossRef]

12. Dillehay, T.D.; Kolata, A.L. Long-term human response to uncertain environmental conditions in the Andes. Proc. Natl. Acad. Sci. USA 2004, 101, 4325-4330. [CrossRef]

13. Kennett, D.J.; Marwan, N. Climatic volatility, agricultural uncertainty, and the formation, consolidation and breakdown of preindustrial agrarian states. Philos. Trans. R. Soc. A 2015, 373, 20140458. [CrossRef]

14. Gade, D.W. Nature and Culture in the Andes; University of Wisconsin Press: Madison, WI, USA, 1999; ISBN 978-0-299-16124-8. 
15. Cooke, C.A.; Balcom, P.H.; Biester, H.; Wolfe, A.P. Over three millennia of mercury pollution in the Peruvian Andes. Proc. Natl. Acad. Sci. USA 2009, 106, 8830-8834. [CrossRef]

16. Capparelli, A.; Lema, V.; Giovannetti, M.; Raffino, R. The introduction of Old World crops (wheat, barley and peach) in Andean Argentina during the 16th century A.D.: Archaeobotanical and ethnohistorical evidence. Veg. Hist. Archaeobot. 2005, 14, 472-484. [CrossRef]

17. De France, S.D. Diet and provisioning in the high Andes: a Spanish colonial settlement on the outskirts of Potosí, Bolivia. Int. J. Hist. Archaeol. 2003, 7, 99-125. [CrossRef]

18. Cade, D.W. Landscape, system, and identity in the post-conquest Andes. Ann. Assoc. Am. Geogr. 1992, 82, 460-477. [CrossRef]

19. Bush, M.B.; Hanselman, J.A.; Hooghiemstra, H. Andean montane forests and climate change. In Tropical Rainforests Responses to Climate Change; Springer: New York, NY, USA, 2007; pp. 33-54. ISBN 978-3-642-05383-2.

20. Weng, C.; Bush, M.B.; Curtis, J.H.; Kolata, A.L.; Dillehay, T.D.; Binford, M.W. Deglaciation and Holocene climate change in the western Peruvian Andes. Quat. Res. 2006, 66, 87-96. [CrossRef]

21. Urrego, D.H.; Silman, M.R.; Correa-Metrio, A.; Bush, M.B. Pollen-vegetation relationships along steep climatic gradients in western Amazonia. J. Veg. Sci. 2011, 22, 795-806. [CrossRef]

22. Hanselman, J.A.; Gosling, W.D.; Paduano, G.M.; Bush, M.B. Contrasting pollen histories of MIS 5e and the Holocene from Lake Titicaca (Bolivia/Peru). J. Quat. Sci. 2005, 20, 663-670. [CrossRef]

23. Gosling, W.D.; Hanselman, J.A.; Knox, C.; Valencia, B.G.; Bush, M.B. Long-term drivers of change in Polylepis woodland distribution in the central Andes. J. Veg. Sci. 2009, 20, 1041-1052. [CrossRef]

24. Capriles, J.M. Mobile communities and pastoralist landscapes during the Formative Period in the Central Altiplano of Bolivia. Lat. Am. Antiq. 2014, 25, 3-26. [CrossRef]

25. Baker, P.A.; Fritz, S.C. Nature and causes of Quaternary climate variation of tropical South America. Quat. Sci. Rev. 2015, 124, 31-47. [CrossRef]

26. Hastorf, C.A.; Whitehead, W.T.; Johannessen, S. Late prehistoric wood use in an Andean intermontane valley. Econ. Bot. 2005, 59, 337-355. [CrossRef]

27. Capriles, J.M. The Economic Organization of Early Camelid Pastoralism in the Andean Highlands of Bolivia; BAR International Series; BAR Publishing: Oxford, UK, 2014; Volume 2597, ISBN 978-1-4073-1229-3.

28. Vining, B.R.; Steinman, B.A.; Abbott, M.B.; Woods, A. Paleoclimatic and archaeological evidence from Lake Suches for highland Andean refugia during the arid middle-Holocene. Holocene 2018. [CrossRef]

29. Kessler, M. Present and potential distribution of Polylepis (Rosaceae) forests in Bolivia. In Biodiversity and Conservation of Neotropical Montane Forests; New York Botanical Garden: New York, NY, USA, 1995; pp. 281-294. ISBN 0893273902.

30. Kessler, M. The "Polylepis problem": Where do we stand? Ecotropica 2002, 8, 97-110.

31. Paduano, G.M.; Bush, M.B.; Baker, P.A.; Fritz, S.C.; Seltzer, G.O. A vegetation and fire history of Lake Titicaca since the Last Glacial Maximum. Palaeogeogr. Palaeoclimatol. Palaeoecol. 2003, 194, 259-279. [CrossRef]

32. Capriles, J.M.; Flores Bedregal, E. The economic, symbolic, and social importance of the "kenua" (Polylepis spp.) during prehispanic times in the Andean highlands of Bolivia. Ecotropica 2002, 8, 225-231.

33. Baied, C.A.; Wheeler, J.C. Evolution of high Andean puna ecosystems: Environment, climate, and culture change over the last 12,000 years in the Central Andes. Mt. Res. Dev. 1993, 13, 145-156. [CrossRef]

34. Hanselman, J.A.; Bush, M.B.; Gosling, W.D.; Collins, A.; Knox, C.; Baker, P.A.; Fritz, S.C. A 370,000-year record of vegetation and fire history around Lake Titicaca (Bolivia/Peru). Palaeogeogr. Palaeoclimatol. Palaeoecol. 2011, 305, 201-214. [CrossRef]

35. Williams, J.J.; Gosling, W.D.; Brooks, S.J.; Coe, A.L.; Xu, S. Vegetation, climate and fire in the eastern Andes (Bolivia) during the last 18,000 years. Palaeogeogr. Palaeoclimatol. Palaeoecol. 2011, 312, 115-126. [CrossRef]

36. Reese, C.A.; Liu, K.B.; Thompson, L.G. An ice-core pollen record showing vegetation response to Late-glacial and Holocene climate changes at Nevado Sajama, Bolivia. Ann. Glaciol. 2013, 54, 183-190. [CrossRef]

37. Kuentz, A.; Ledru, M.-P.; Thouret, J.-C. Environmental changes in the highlands of the western Andean Cordillera, southern Peru, during the Holocene. Holocene 2011, 22, 1215-1216. [CrossRef]

38. Rundel, P.W.; Palma, B. Preserving the unique puna ecosystems of the Andean Altiplano. Mt. Res. Dev. 2000, 20, 262-271. [CrossRef]

39. Beck, S.G.; Domic, A.I.; Garcia, C.; Meneses, R.I.; Yager, K.; Halloy, S. El Parque Nacional Sajama y sus Plantas; Herbario Nacional de Bolivia, Fundacion PUMA: La Paz, Bolivia, 2010; ISBN 978-99905-48-01-3. 
40. Ruthsatz, B. Vegetation and ecology of the high Andean peatlands of Bolivia. Phytocoenologia 2012, 42, 133-179. [CrossRef]

41. Meneses, R.I.; Domic, A.I.; Beck, S.G.; Yager, K. Bofedales Altoandinos: Oasis en La Puna; Herbario Nacional de Bolivia: La Paz, Bolivia, 2018.

42. Squeo, F.A.; Warner, B.G.; Aravena, R.; Espinoza, D. Bofedales: High altitude peatlands of the central Andes. Rev. Chil. Hist. Nat. 2006, 79, 245-255. [CrossRef]

43. Pfister, J.A.; Martin, F.S.; Rosales, L.; Sisson, D.V.; Flores, E.; Bryant, F.C. Grazing behavior of llamas, alpacas and sheep in the Andes of Peru. Appl. Anim. Behav. Sci. 1989, 23, 237-246. [CrossRef]

44. Bengtsson, L.; Enell, M. Chemical analysis. In Handbook of Holocene Palaeoecology and Palaeohydrology; John Wiley: Chichester, UK, 1986; pp. 423-451; ISBN 1930665806.

45. Heiri, O.; Lotter, A.F.; Lemcke, G. Loss on ignition as a method for estimating organic and carbonate content in sediments: Reproducibility and comparability of results. J. Paleolimnol. 2001, 25, 101-110. [CrossRef]

46. Faegri, K.; Iversen, J. Textbook of Pollen Analysis, 4th ed.; John Wiley: Chichester, UK, 1989.

47. Roubik, D.W.; Moreno, E. Pollen and Spores of Barro Colorado Island; Missouri Botanical Garden: Saint Louis, MO, USA, 1981.

48. Sandoval, A.P.; Marconi, L.; Ortuño, T. Flora Polinica de Bofedales y Zonas Aledañas del Tuni Condoriri; Herbario Nacional de Bolivia: La Paz, Bolivia, 2011.

49. Bush, M.B.; Weng, C. Introducing a new (freeware) tool for palynology. J. Biogeogr. 2007, 34, $377-380$. [CrossRef]

50. Collao-Alvarado, K.; Maldonado, A.; González, L.; Sandoval, A.; De Porras, M.E.; Zamora, A.; Arancio, G. Estudio de la relación polen-vegetación actual en el Norte de Chile, en el transecto Pozo Almonte-Salar de Huasco $\left(20^{\circ} 15^{\prime} \mathrm{S} / 69^{\circ} 06^{\prime} \mathrm{O}\right)$. Gayana Botánica 2018, 72, 0717-6643. [CrossRef]

51. Walsh, M.K.; Prufer, K.M.; Culleton, B.J.; Kennett, D.J. A late Holocene paleoenvironmental reconstruction from Agua Caliente, southern Belize, linked to regional climate variability and cultural change at the Maya polity of Uxbenká. Quat. Res. 2014, 82, 38-50. [CrossRef]

52. Hogg, A.G.; Hua, Q.; Blackwell, P.G.; Niu, M.; Buck, C.E.; Guilderson, T.P.; Heaton, T.J.; Palmer, J.G.; Reimer, P.J.; Reimer, R.W.; et al. SHCal13 Southern Hemisphere Calibration, 0-50,000 years cal BP. Radiocarbon 2013, 55, 1889-1903. [CrossRef]

53. Blaauw, M.; Christen, A.J. Flexible paleoclimate age-depth models using an autoregressive gamma process. Bayesian Anal. 2011, 6, 457-474. [CrossRef]

54. De Porras, M.E.; Maldonado, A.; De Pol-Holz, R.; Betancourt, J.L. Late Quaternary environmental dynamics in the Atacama Desert reconstructed from rodent midden pollen records. J. Quat. Sci. 2017, 32, 665-684. [CrossRef]

55. Grimm, E.C. Tilia: Version 1.5.12; Illinois State Museum: Springfield, MA, USA, 2011.

56. Wirrmann, D.; De Oliveira Almeida, L.F. Low Holocene level (7700 to 3650 years ago) of Lake Titicaca (Bolivia). Palaeogeogr. Palaeoclimatol. Palaeoecol. 1987, 59, 315-323. [CrossRef]

57. Tapia, P.M.; Fritz, S.C.; Baker, P.A.; Seltzer, G.O.; Dunbar, R.B. A Late Quaternary diatom record of tropical climatic history from Lake Titicaca (Peru and Bolivia). Palaeogeogr. Palaeoclimatol. Palaeoecol. 2003, 194, 139-164. [CrossRef]

58. Pueyo, J.J.; Sáez, A.; Giralt, S.; Valero-Garcés, B.L.; Moreno, A.; Bao, R.; Schwalb, A.; Herrera, C.; Klosowska, B.; Taberner, C. Carbonate and organic matter sedimentation and isotopic signatures in Lake Chungará, Chilean Altiplano, during the last 12.3 kyr. Palaeogeogr. Palaeoclimatol. Palaeoecol. 2011, 307, 339-355. [CrossRef]

59. Ledru, M.-P.; Jomelli, V.; Samaniego, P.; Vuille, M.; Hidalgo, S.; Herrera, M.; Ceron, C. The Medieval Climate Anomaly and the Little Ice Age in the eastern Ecuadorian Andes. Clim. Past 2013, 9, 307-321. [CrossRef]

60. Tchilinguirian, P.; Morales, M.R. Mid-Holocene paleoenvironments in northwestern Argentina: Main patterns and discrepancies. Quat. Int. 2013, 307, 14-23. [CrossRef]

61. Moreno, A.; Giralt, S.; Valero-Garcés, B.; Sáez, A.; Bao, R.; Prego, R.; Pueyo, J.J.; González-Sampériz, P.; Taberner, C. A $14 \mathrm{kyr}$ record of the tropical Andes: The Lago Chungará sequence $\left(18^{\circ} \mathrm{S}\right.$, northern Chilean Altiplano). Quat. Int. 2007, 161, 4-21. [CrossRef]

62. Grosjean, M.; Núñez, A.L. Lateglacial, early and middle Holocene environments, human occupation, and resource use in the Atacama (Northern Chile). Geoarchaeology 1994, 9, 271-286. [CrossRef] 
63. Grosjean, M.; Geyh, M.A.; Messerli, B.; Schotterer, U. Late-glacial and early Holocene lake sediments, ground-water formation and climate in the Atacama Altiplano 22-24 S. J. Paleolimnol. 1995, 14, 241-252. [CrossRef]

64. Grosjean, M.; Núñez, L.; Cartajena, I.; Messerli, B. Mid-Holocene climate and culture change in the Atacama desert, Northern Chile. Quat. Res. 1997, 48, 239-246. [CrossRef]

65. Grosjean, M.; van Leeuwen, J.F.N.; van der Knaap, W.O.; Geyh, M.A.; Ammann, B.; Tanner, W.; Messerli, B.; Núñez, L.A.; Valero-Garcés, B.L.; Veit, H. A 22,000 14C year BP sediment and pollen record of climate change from Laguna Miscanti (23 S), northern Chile. Glob. Planet. Chang. 2001, 28, 35-51. [CrossRef]

66. Núñez, L.; Loyola, R.; Cartajena, I.; López, P.; Santander, B.; Maldonado, A.; de Souza, P.; Carrasco, C. Miscanti-1: Human occupation during the arid Mid-Holocene event in the high-altitude lakes of the Atacama Desert, South America. Quat. Sci. Rev. 2018, 181, 109-122. [CrossRef]

67. Grosjean, M.; Valero-Garcés, B.L.; Geyh, M.A.; Messerli, B.; Schotterer, U.; Schreier, H.; Kelts, K. Midand late-Holocene limnogeology of Laguna del Negro Francisco, northern Chile, and its palaeoclimatic implications. Holocene 1997, 7, 151-159. [CrossRef]

68. Grosjean, M.; Geyh, M.A.; Messerli, B.; Schreier, H.; Veit, H. A late-Holocene (<2600 BP) glacial advance in the south-central Andes ( $\left.29^{\circ} \mathrm{S}\right)$, northern Chile. Holocene 1998, 8, 473-479. [CrossRef]

69. Latorre, C.; Betancourt, J.L.; Rylander, K.A.; Quade, J.; Matthei, O. A vegetation history from the arid prepuna of northern Chile $\left(22-23^{\circ}\right.$ S) over the last 13,500 years. Palaeogeogr. Palaeoclimatol. Palaeoecol. 2003, 194, 223-246. [CrossRef]

70. Latorre, C.; Betancourt, J.L.; Arroyo, M.T.K. Late Quaternary vegetation and climate history of a perennial river canyon in the Río Salado basin $\left(22^{\circ} \mathrm{S}\right)$ of northern Chile. Quat. Res. 2006, 65, 450-466. [CrossRef]

71. Mujica, M.I.; Latorre, C.; Maldonado, A.; González-Silvestre, L.; Pinto, R.; de Pol-Holz, R.; Santoro, C.M. Late Quaternary climate change, relict populations and present-day refugia in the northern Atacama Desert: A case study from Quebrada La Higuera (18 S). J. Biogeogr. 2015, 42, 76-88. [CrossRef]

72. Valero-Garcés, B.; Grosjean, M.; Schwalb, A.; Geyh, M.; Messerli, B.; Kelts, K. Limnogeology of Laguna Miscanti: Evidence for mid to late Holocene moisture changes in the Atacama Altiplano (Northern Chile). J. Paleolimnol. 1996, 16, 1-21. [CrossRef]

73. Schittek, K.; Kock, S.T.; Lücke, A.; Hense, J.; Ohlendorf, C.; Kulemeyer, J.J.; Lupo, L.C.; Schäbitz, F. A high-altitude peatland record of environmental changes in the NW Argentine Andes ( $\left.24^{\circ} \mathrm{S}\right)$ over the last 2100 years. Clim. Past 2016, 12, 1165-1180. [CrossRef]

74. Thompson, L.G.; Davis, M.E.; Mosley-Thompson, E.; Sowers, T.A.; Henderson, K.A.; Zagorodnov, V.S.; Lin, P.-N.; Mikhalenko, V.N.; Campen, R.K.; Bolzan, J.F.; et al. A 25,000-year tropical climate history from Bolivian ice cores. Science 1998, 282, 1858-1864. [CrossRef] [PubMed]

75. Thompson, L.G.; Mosley-Thompson, E.; Bolzan, J.F.; Koci, B.R. A 1500-year record of tropical precipitation in ice cores from the Quelccaya ice cap, Peru. Science 1985, 229, 971-973. [CrossRef] [PubMed]

76. Thompson, L.G.; Mosley-Thompson, E.; Dansgaard, W.; Grootes, P.M. The Little Ice Age as recorded in the stratigraphy of the tropical Quelccaya ice cap. Science 1986, 234, 361-364. [CrossRef] [PubMed]

77. Morales, M.S.; Christie, D.A.; Villalba, R.; Argollo, J.; Pacajes, J.; Silva, J.S.; Alvarez, C.A.; Llancabure, J.C.; Gamboa, C.S. Precipitation changes in the South American Altiplano since 1300 AD reconstructed by tree-rings. Clim. Past 2012, 8, 653-666. [CrossRef]

78. Liu, K.; Reese, C.A.; Thompson, L.G. Ice-core pollen record of climatic changes in the central Andes during the last 400 yr. Quat. Res. 2005, 64, 272-278. [CrossRef]

79. Baied, C.A. Distribución actual de matorrales altoandinos de Polylepis en los Andes Centro-Sur: Oscilaciones climáticas y el impacto de la actividad humana en el pasado. In En los Tres Reinos: Prácticas de Recolección en el cono sur de América; Universidad Nacional de Tucumán: Tucumán, Argentina, 1999; pp. 129-139.

80. Rodríguez, F.; Behling, H. Late Quaternary vegetation, climate and fire dynamics, and evidence of early to mid-Holocene Polylepis forests in the Jimbura region of the southernmost Ecuadorian Andes. Palaeogeogr. Palaeoclimatol. Palaeoecol. 2012, 350-352, 247-257. [CrossRef]

81. Moreno, A.; Santoro, C.M.; Latorre, C. Climate change and human occupation in the northernmost Chilean Altiplano over the last ca. 11500 cal. a BP. J. Quat. Sci. 2008, 24, 373-382. [CrossRef]

82. Allen, J.R.M.; Huntley, B. Effects of tephra falls on vegetation: A Late-Quaternary record from southern Italy. J. Ecol. 2018, 106, 2456-2472. [CrossRef] 
83. Santoro, C.M.; Núñez, L. Hunters of the dry Puna and the salt Puna in northern Chile. Andean Past 1987, 1, 57-109.

84. Osorio, D.; Steele, J.; Sepúlveda, M.; Gayo, E.M.; Capriles, J.M.; Herrera, K.; Ugalde, P.; De Pol-Holz, R.; Latorre, C.; Santoro, C.M. The dry Puna as an ecological megapatch and the peopling of South America: Technology, mobility, and the development of a late Pleistocene/early Holocene Andean hunter-gatherer tradition in northern Chile. Quat. Int. 2017, 461, 41-53. [CrossRef]

85. Osorio, D.; Jackson, D.; Ugalde, P.C.; Latorre, C.; De Pol-Holz, R.; Santoro, C.M. Hakenasa Cave and its relevance for the peopling of the southern Andean Altiplano. Antiquity 2011, 85, 1194-1208. [CrossRef]

86. Núñez, L.; Cartajena, I.; Grosjean, M. Archaeological silence and ecorefuges: Arid events in the Puna of Atacama during the middle Holocene. Quat. Int. 2013, 307, 5-13. [CrossRef]

87. Vining, B.R. Pastoral intensification, social fissioning, and ties to state economies at the formative period-middle horizon transition in the Lake Suches region, southern Peru. In The Archaeology of Andean Pastoralism; University of New Mexico Press: Alburquerque, NM, USA, 2016; ISBN 978-0-8263-5703-8.

88. Aragón, R.; Carilla, J.; Cristóbal, L. Fire, plant species richness and aerial biomass distribution in mountain grasslands of NW Argentina. In Land Use Change and Mountain Biodiversity; Taylor \& Francis Group: Boca Raton, FL, USA, 2006; pp. 89-99. ISBN 9780849335235.

89. Carilla, J.; Aragón, R.; Gurvich, D.E. Fire and grazing differentially affect aerial biomass and species composition in Andean grasslands. Acta Oecol. 2011, 37, 337-345. [CrossRef]

90. Patty Aguilar, L.B. Effects of Grazing and Fire on Herbaceous Species in the Bolivian Altiplano. Ph.D. Thesis, University of Basel, Basel, Switzerland, 2012.

91. Verzijl, A.; Quispe, S.G. The system nobody sees: Irrigated wetland management and alpaca herding in the Peruvian Andes. Mt. Res. Dev. 2013, 33, 280-293. [CrossRef]

92. Lane, K.; Grant, J. A question of altitude: Exploring the limits of highland pastoralism in the prehispanic Andes. In The Archaeology of Andean Pastoralism; University of New Mexico Press: Alburquerque, NM, USA, 2016; pp. 139-157.

93. Castellaro, G.; Squella, F.; León, F.; Raggi, A. Composición botánica de la dieta de alpaca (Lama pacos Linn.) en un pastizal del secano mediterráneo de la zona central de Chile. Chil. J. Agric. Res. 2008, 68, 136-145. [CrossRef]

94. Borgnia, M.; Vilá, B.L.; Cassini, M.H. Interaction between wild camelids and livestock in an Andean semi-desert. J. Arid Environ. 2008, 72, 2150-2158. [CrossRef]

95. Machaca, N.C.; Condori, B.; Pardo, A.R.; Anthelme, F.; Meneses, R.I.; Weeda, C.E.; Perotto-Baldivieso, H.L. Effects of grazing pressure on plant species composition and water presence on bofedales in the Andes mountain range of Bolivia. Mires Peat 2018, 21, 1-15.

96. Villarroel, E.K.; Pacheco Mollinedo, P.L.; Domic, A.I.; Capriles, J.M.; Espinoza, C. Local management of Andean wetlands in Sajama National Park, Bolivia. Mt. Res. Dev. 2014, 34, 356-368. [CrossRef]

97. López-i-Gelats, F.; Contreras Paco, J.L.; Huilcas Huayra, R.; Siguas Robles, O.D.; Quispe Peña, E.C.; Bartolomé Filella, J. Adaptation strategies of Andean pastoralist households to both climate and non-climate changes. Hum. Ecol. 2015, 43, 267-282. [CrossRef]

98. Bruno, M.C.; Hastorf, C.A. Gifts from the camelids: Archaeobotanical insights into camelid pastoralism through the study of dung. In The Archaeology of Andean Pastoralism; University of New Mexico Press: Alburquerque, NM, USA, 2016; pp. 55-65; ISBN 978-0-8263-5703-8.

99. Markemann, A.; Valle Zárate, A. Traditional llama husbandry and breeding management in the Ayopaya region, Bolivia. Trop. Anim. Health Prod. 2009, 42, 79. [CrossRef]

100. Villagrán, M.C.; Castro, R.V. Etnobotánica y manejo ganadero de las vegas, bofedales y quebradas en el Loa Superior, Andes de Antofagasta, Segunda Región, Chile. Chungara 1997, 29, 275-304.

101. Chimmer, R.A.; Bonvissuto, G.L.; Cremona, M.V.; Gaitan, J.J.; López, C.R. Ecohydrological conditions of wetlands along a precipitation gradient in Patagonia, Argentina. Ecol. Aust. 2011, 21, 329-337.

102. Flantua, S.; Hooghiemstra, H.; Vuille, M.; Behling, H.; Carson, J.F.; Gosling, W.D.; Hoyos, I.; Ledru, M.P.; Montoya, E.; Mayle, F.; et al. Climate variability and human impact in South America during the last 2000 years: Synthesis and perspectives from pollen records. Clim. Past 2016, 12, 483-523. [CrossRef]

103. Loughlin, N.J.D.; Gosling, W.D.; Coe, A.L.; Gulliver, P.; Mothes, P.; Montoya, E. Landscape-scale drivers of glacial ecosystem change in the montane forests of the eastern Andean flank, Ecuador. Palaeogeogr. Palaeoclimatol. Palaeoecol. 2018, 489, 198-208. [CrossRef] 
104. Rozas, V.; Le Quesne, C.; Rojas-Badilla, M.; González, M.E.; González-Reyes, A. Coupled human-climate signals on the fire history of upper Cachapoal Valley, Mediterranean Andes of Chile, since 1201 CE. Glob. Planet. Chang. 2018, 167, 137-147. [CrossRef]

105. Dobyns, H.F. An outline of Andean epidemic history to 1720. Bull. Hist. Med. 1963, 37, 493-515. [PubMed]

106. Brading, D.A.; Cross, H.E. Colonial silver mining: Mexico and Peru. Hisp. Am. Hist. Rev. 1972, 52, 545-579. [CrossRef]

107. Newson, L.A. The demographic collapse of native peoples of the Americas, 1492-1650. Proc. Br. Acad. 1993, 81, 247-288.

108. Lima, M.; Christie, D.A.; Santoro, M.C.; Latorre, C. Coupled socio-environmental changes triggered indigenous Aymara depopulation of the semiarid Andes of Tarapacá-Chile during the late 19th-20th centuries. PLoS ONE 2016, 11, e0160580. [CrossRef]

109. Van Kessel, J. Holocausto al Progreso: Los Aymarás de Tarapacá, 1st ed.; IECTA: Iquique, Chile, 1992; ISBN 9070280523.

(C) 2018 by the authors. Licensee MDPI, Basel, Switzerland. This article is an open access article distributed under the terms and conditions of the Creative Commons Attribution (CC BY) license (http:/ / creativecommons.org/licenses/by/4.0/). 